\title{
Theory and Empirical Evidence on Corporate Governance from Banking Sector of Pakistan
}

\author{
Waqas Tariq (Corresponding Author) \\ Hailey College of Commerce, University of the Punjab, Lahore, Pakistan \\ Tel: 92-322-734-0263Ｅ-mail: tariq.waqas@ymail.com
}

Imran Ali

Hailey College of Commerce, University of the Punjab, Lahore, Pakistan

Tel: 92-345-443-6600Ｅ-mail: alihcc1927@gmail.com

\begin{abstract}
Muhammad Ibrahim
Hailey College of Commerce, University of the Punjab, Lahore, Pakistan

E-mail: muhammadibrahim1987@gmail.com
\end{abstract}

Muhammad Asim

Virtual University of Pakistan, Lahore, Pakistan

E-mail: asimrafiq2004@gmail.com

\begin{abstract}
Naeem Ur Rehman
Comsats Institute of Information Technology, Lahore, Pakistan

E-mail: joinnaeem@ymail.com
\end{abstract}

Received: January 21, 2014 Accepted: February 3, 2014

doi:10.5296/ber.v4i1.5180 URL: http://dx.doi.org/10.5296/ber.v4i1.5180

\section{Abstract}

Economic system appears to be best if they provide according to what people want. The 
purpose of this study is to investigate the effectiveness of corporate governance on financial efficiency of banks in Pakistan. The time period of this study is 2007 to 2012, and sample of 17 listed banks are selected and data is taken from their financial reports from their websites and Lahore Stock Exchange. Financial efficiency is measured by fix\& random effects model techniques, for the measurement of dependent variable financial efficiency two proxies return on asset (ROA) and return on equity (ROE) are used. The independent variable includes Board size, Board meeting, Non-Executive directors, Bank size and leverage. The result of this research is consistent with the research conducted on corporate governance that shows significant positive impact on the financial efficiency of the bank. This study is contributed to the literature towards the corporate governance effect on financial performance of banks. Corporate governance provides rules \& regulations to monitor and manage bank affairs, and it provide guidelines to board of directors how to run the affairs and how to increase shareholder values and increase bank efficiency. For the calculation of results STATA is used.

Keywords: Financial Efficiency, Corporate Governance, Board of Directors, Banking Sector

\section{Introduction}

Development of financial sector is necessary for the progress of the economy. It is inter-related with economy growth. It is difficult to attain economic development without efficiently working of financial sector. Banks are the integral part of the financial sector, in order to attain economic prosperity it is essential to develop well organized banking sector. Bank is an institution which deals with deposits, advances and other services. Bank accepts deposits at low rate of interest and lends it at high rate to those who need it. It performs its function efficiently and effectively at every sphere of life, so we cannot deny the importance of banking sector in the progress of the economy. Research on banking sector finds that it enhances economy growth (Levine, 2006).

Banks have important role in growth and development of an economy where it ensures prudent allocation of capital resources and their efficient utilization; whereas it is implausible to work smoothly in modern time without robust banking system (Haque and Tariq, 2012).Pakistan banking had experienced turmoil since the time of independence. At the time of independence it had faced difficulties in the area of resources and funds, trained human resource, uncertain political and economic environments. It faced challenges of nationalization and reforms of The State Bank of Pakistan. The main objective of these operations is to increase the efficiency of banking sector, to improve the governance of banks and to provide services efficiently to all areas of the economy.

The word corporate governance explains the connection among management, board of directors, shareholders and other stakeholder in the company. Corporate governance is basically some rules inspiring the persons to participate actively in the functioning of the corporation provides its full intention to safe organization interests and promotes the net-worth of shareholders.

Corporate governance is defined "as the shareholder whom they invested in the organizations they rely on that they get the greater profit from their investment in the organization" (Shleifer 
and Vishny, 1997).

Corporate governance is defined "the organization of rules, regulations and components that prepare actions of the corporations" (Gillan and Starks, 1998).

Corporate governance is defined "the manner through organizations are organized and provide the environment of answer ability to the managers in front of the controller of the organization" (Hussey, 1999).

Importance of corporate governance has increased in the literature and business field after decay of leading corporations like World call, Enron, Lehman Brothers, Merrill Lynch, Barings Bank, ABN Amro and many others. An accurate administration of corporate governance method helps a corporation to pursue opportunities, increases shareholder value and result of these operations improves bank financial efficiency.

Board is the heart of the corporation and its effectiveness is very important for the governance of the corporation. Board that does well and shows effectiveness in monitoring, produces good governance and creates shareholder value. Bank board must evaluate their performance according to the rule of governance. Choe and Lee (2003) argue that composition of board is an essential part of the management to monitor the managers in a better way and lessen the agency cost.

\subsection{Significance of the Study}

The banking sector role in the progress of the economy cannot overlook. Banking sector financial efficiency has importance for the growth of bank itself, if banking sector performs well than it participates in the growth of the economy. Its failure brings harmful consequences to the progress of the economy. So governance of banking sector has much importance, Board of director plays main role towards the improvement of the governance in the bank.

\subsection{Objective of the Study}

The objective of study is to know how corporate governance effects financial efficiency of banking sector for the period of 2007-2012. The purpose of this research is to fill the gap which is presented in the literature.

\section{Literature Review}

Economic system appears to be the best because they provide according to what the people want (Galbraith, 1975). In economic system banking sector is the main stakeholder, in other words backbone of the economy. The governance of banking sector has a focal point for developing countries. In Pakistan corporate governance has become main issue of research. Cheema(2003) states that corporate governance for the development of economy pursue foreign direct investment and mobilize savings through revenue contributed by the corporate governance structure is well matched to the intention of increasing external capital by capital markets. A large number of researchers believe that poor handling of corporate sector becomes the cause of 1997/1998 economic crises (Spremann, 2002; Clarke, 2004; Connelly and Limpaphayom, 2004; Mueller, 2006). Financial crises of East Asian countries become the 
significant point for evaluating the corporate governance in developing countries.

Financial efficiency is the main issue for banking sector, if bank performs well than it has financial resources to obtain the corporate goal and to alive the hope of survival in the competitive market. Researchers on the basis of results of empirical findings find the mixed relationship between corporate governance and firm performance (Yermack, 1996; Claessens et al., 2000; Klapper and Love, 2002; Gompers et al., 2003; Black et al., 2003; Anda et al., 2005). Weir et al. (1999) and Bhagat et al. (2000)find a positive relationship between corporate governance and firm performance on the other hand, Albeit et al. (1998) find a negative relationship between corporate governance and firm performance.

Board is the heart of corporate governance because it takes the decision and is responsible for actions which decide the future of corporation (Fama and Jensen, 1983; Finkelstein and Hambrick, 1996; Donaldson, 2003; Gillan, 2006; Yawson, 2006;Adjaoud et al., 2007; Clarke, 2007; Guerra et al., 2009).Ong and Wan (2008) argue that corporate financial performance is the consequenceof practicality presented by the boards. Board of directors is the main body which regulates the internal governace of the corporation. Gillian (2006) found that board is one of the main effective part of inside governance mechanism of the corporation. In the corporation, ownership and control is separate, board has a part of intermediary in the corporation that confines and govern the link between the managers and shareholders (John and Senbet, 1998; Stiles and Taylor, 2001).

Board under the guideline of corporate governance has solved the conflict between manager and shareholder, also improved the bank financial performance and reduced the agency cost. Agency theory examines the role of boards toward the financial performance of corporation which they control (Jackling and Johl, 2009).Size of board has much importance in the corporation because it supervises the management and takes more human capital to advise management (Caprio, Laeven, \& Levine, 2007; Andres \&Vallelado, 2008). Javid and Iqbal (2008) and Yasser. Enterbang, and Mansor, (2011) find positive relationship between board size and firm efficiency. The findings of Yermack (1996); Eisenberg et al. (1998); Mak and Kusnadi (2004); and Andres et al. (2005) specify that there is negative relationship between board size and firm efficiency.

Board meeting is another variable source used in this study. Conger et al. (1998) describes that to arrange meetings on proper time will increase the accuracy and efficiency of the board. Board has adequate number of meetings in a year to improve the financial efficiency and to increase the value of shareholder. In the US, six meetings in a year in substitute month appear to be good practice for a number of organizations and also contain special meetings (Moore, 2002).Board must meet 4 times in a year; also include executive committee attended by CEO, chairman directors, managers and directors (Ward, 1991). Vefeas (1999) found in his empirical result that numbers of board meetings show a positive link between the board meetings and firm efficiency. Yasser (2011) finds the negative link between board meetings and firm efficiency.

Non-executive director participation in the board increases the efficiency of the decision and it also monitors the affair of corporation in a better way. The purpose of involvement in the board 


\section{Macrothink}

Business and Economic Research ISSN 2162-4860 2014, Vol. 4, No. 1

is to protect and increase the value of shareholder. Their participation in board brings new windows of universe (Tricker, 1984). They safeguard the interest of shareholder from the management. (Weisbach, 1988; Liang and Li, 1999; Prevost et al., 2002; McKnight and Mira, 2003; Anderson and Reeb, 2004; Bozec and Dia, 2005; Krivogorsky, 2006; Rebeiz and Salameh, 2006) find a positive and significant relationship between outsider directors and firm value. But, some others like Baysinger and Butler (1985); Hermalin and Weisbach (1991); Agrawal and Knoeber (1996); Yasser (2011) find a negative relationship between the outside directors and firm performance.

\section{Methodology}

\subsection{Data and Sources}

Secondary data is used for this study. Panel data has been taken from the financial reports of the banks of Lahore Stock Exchange. Panel data is a mixture of cross sectional and time series data. It removes the unobservable heterogeneity present in the data of different companies (Himmel berg, et al., 1999). Sample is comprised of 17 banks for the period of 2007 to 2012 listed in stock exchange.

\subsection{Econometric Model.}

Now we present our empirical model of the study. The dependent variable is the financial efficiency of the banks and independent variables are board size, board meeting, non-executive directors, bank size and leverage.

\section{$E f f=\beta_{0}+\beta_{1} B Z_{i t}+\beta_{2} B M_{i t}+\beta_{3} N E D_{i t}+\beta_{4} B K Z_{i t}+\beta_{5} L E_{i t}+e_{i t}$}

$\mathrm{i}=1$ to 17 banks

$t=2007-2012$

$\mathrm{e}_{\mathrm{it}}=$ Error term.

Where

\subsection{Variables}

\begin{tabular}{|l|l|l|}
\hline Variables & $\begin{array}{l}\text { Denoted } \\
\text { By }\end{array}$ & \\
\hline Efficiency & Eff & $\begin{array}{l}\text { Efficiency is measured by (ROE) Return on Equity and (ROA) Return } \\
\text { on Asset }\end{array}$ \\
\hline Board Size & BZ & Log of total number of members in board \\
\hline
\end{tabular}




\begin{tabular}{|l|l|l|}
\hline Board Meeting & BM & Meetings held by the board in the year \\
\hline Non-Executive & NED & Total non-executive directors divided by total member in boards \\
\hline Bank Size & BKZ & Calculated by log of Total Assets \\
\hline Leverage & LE & Calculated by Total debts over Total equity \\
\hline
\end{tabular}

\subsection{Hypothesis Development}

Hypothesis development of the study: is it nulls or alternates hypothesis

$\mathrm{H}_{1}$ : Board size has significant relationship with bank financial efficiency.

$\mathrm{H}_{2}$ : Board meeting has significant relationship with bank financial efficiency.

$\mathrm{H}_{3}$ : Non-Executive directs has significant relationship with bank financial efficiency.

$\mathrm{H}_{4}$ : Bank size has significant relationship with bank financial efficiency.

$\mathrm{H}_{5}$ : Leverage has significant relationship with bank financial efficiency.

\section{Results and Discussions}

Table 1. Descriptive Statistics Results

\begin{tabular}{|l|c|c|c|c|}
\hline Variables & Mean & Std. Dev & Max. & Min. \\
\hline BZ & 8.68 & 1.64 & 13 & 4 \\
\hline BM & 6.63 & 2.58 & 16 & 4 \\
\hline NED & 6.32 & 2.07 & 12 & 2 \\
\hline BKZ & 5.34 & 0.46 & 6.18 & 4.22 \\
\hline LE & 13.77 & 9.77 & 76.53 & 1.62 \\
\hline ROE & 0.09 & 0.06 & 0.33 & 0.01 \\
\hline ROA & 0.004 & 0.02 & 0.04 & -0.07 \\
\hline
\end{tabular}

Table 1 shows the descriptive statistics result of the variables. Board size means value is 8.68 that shows the reasonable size of board. Brown and Caylor (2004) find that organization having board members between 6 and 15, have greater return on margins and return on equity as contrast to other board sizes in organization. Board meeting mean value is 6.63 that shows board has conducted reasonable meetings in a year. Kama and Chuku (2009) find that board having more than six meetings in a year contributes toward effectiveness of organizations. Non-Executive direcotrs mean value is 6.32 that show great representation in board. Pfeffer and Salancick (1978) find that existence of non-executive directors in board helps to play the efficiency of board as well as financial performance of organization. The mean value of bank size is 5.34 and Leverage is 13.77 . The mean value of dependent variable return on equity is 0.09 and return on asset is 0.004 . 
Table 2. Correlation Matrix

\begin{tabular}{|c|c|c|c|c|c|c|c|}
\hline Variables & BZ & BM & NED & BKZ & LE & ROE & ROA \\
\hline BZ & 1.00 & & & & & & \\
\hline BM & -0.32 & 1.00 & & & & & \\
\hline NED & -0.09 & -0.16 & 1.00 & & & & \\
\hline BKZ & -0.09 & 0.24 & 0.17 & 1.00 & & & \\
\hline LE & 0.09 & 0.31 & -0.09 & 0.15 & 1.00 & & \\
\hline ROE & -0.04 & -0.19 & -0.13 & -0.56 & -0.64 & 1.00 & \\
\hline ROA & 0.10 & -0.13 & 0.09 & 0.54 & -0.24 & -0.21 & 1.00 \\
\hline
\end{tabular}

VIF Mean $=1.39$ which is less than 5 indicating that is causes no problem to multicollineraity.

Table 3. Multicollinearity

\begin{tabular}{|c|c|c|}
\hline & Tolerance & VIF \\
\hline BZ & 0.83 & 1.19 \\
\hline BM & 0.72 & 1.39 \\
\hline NED & 0.91 & 1.10 \\
\hline BKZ & 0.89 & 1.12 \\
\hline LE & 0.86 & 1.17 \\
\hline
\end{tabular}

Table 2 and 3 show that there is no correlation and multicollinearity among variables.

Table 4. Result of Pooled Regression

\begin{tabular}{|l|c|c|c|c|}
\hline \multirow{2}{*}{} & \multicolumn{2}{|c|}{ ROA } & \multicolumn{2}{c|}{ ROE } \\
\cline { 2 - 5 } & Coefficient & P-Value & Coefficient & P-Value \\
\hline BZ & 0.031 & 0.13 & -0.001 & 0.99 \\
\hline BM & -0.001 & $0.07^{* * *}$ & 0.002 & 0.19 \\
\hline NED & -0.007 & 0.44 & -0.030 & 0.19 \\
\hline BKZ & 0.029 & $0.00^{*}$ & -0.066 & $0.00^{*}$ \\
\hline LE & -0.001 & $0.00^{*}$ & -0.044 & $0.00^{*}$ \\
\hline Const & -0.157 & $0.00^{*}$ & 0.508 & $0.00^{*}$ \\
\hline Durbin Watson & \multicolumn{2}{|c|}{1.95} & \multicolumn{2}{c|}{2.02} \\
\hline F-statistics & \multicolumn{2}{|c|}{16.01} & \multicolumn{2}{c|}{33.88} \\
\hline $\mathrm{R}^{2}$ & \multicolumn{2}{|c|}{0.45} & \multicolumn{2}{c|}{0.63} \\
\hline
\end{tabular}

\section{Level of significance}

0.01 at $*, 0.05$ at $* *, 0.10$ at $* * *$

Table 4 shows the result of pooled regression for return on asset. Board Meetings show the negative and significant $(\mathrm{p}<0.10)$ relationship. Yasser $(2011)$ finds the negative link between board meeting and firm performance. The Board size and Non-executive director show insignificant impact on bank financial performance. The Bank size shows positive and significant relationship and Leverage shows negative and significant relationship. The 


\section{Macrothink}

Business and Economic Research

ISSN 2162-4860

2014, Vol. 4, No. 1

F-statistics value shows that overall model is significant.

Table 4 shows the result of pooled regression for return on equity. The Board size, Board meeting and Non-Executive director show insignificant impact on bank financial performance. The Bank size show negative and significant relationship. The F-statistics value show overall model is significant.

Table 5. Result of Fixed and Rendom effect model for ROE and ROA

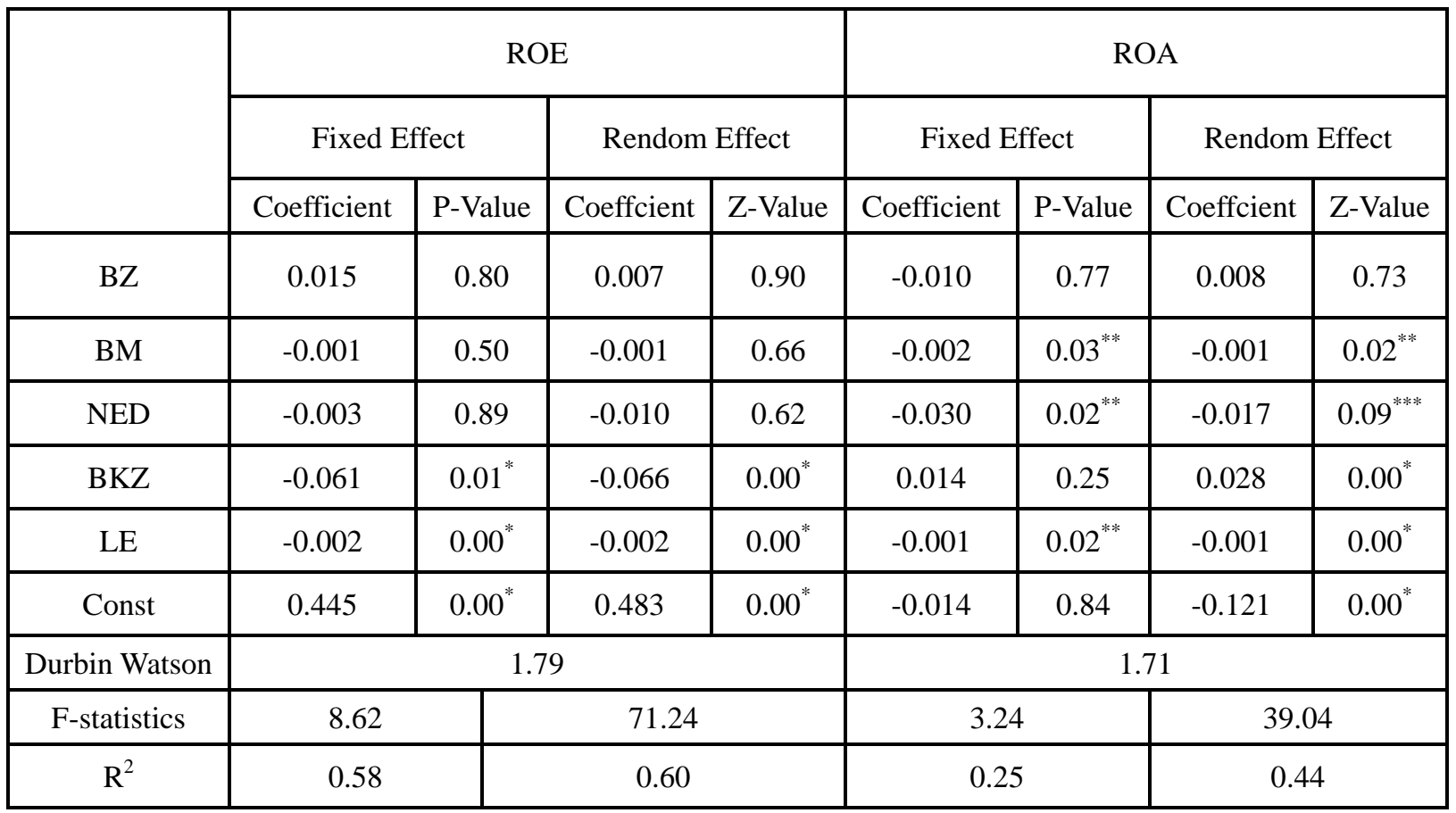

Level of significance

0.01 at $*, 0.05$ at $* *, 0.10$ at $* * *$

According to table 5 the hausman's test recommends that random effect model is most appropriate. The Board size, Board meeting and Non-Executive director show insignificant impact on bank financial performance. The Bank size shows the negative and significant relationship. The F-statistics value shows that overall model is significant.

According to table 5 the hausman test recommends the rendom effect model for return on asset. The Board meeting shows negative and significant relationship at $(\mathrm{p}<0.005)$. Yasser (2011) finds the negative link between board meeting and firm performance. The Non-Executive director shows negative and significant relationship at $(\mathrm{p}<0.10)$. The F-statistics value shows that overall model is significant.

\section{Conclusion\& Recommendations}

Financial sector is playing main role towards the development of economic system of the country. Banking sector progress is essential if we want economy on the path of success. This study is focused on financial efficiency of banking sector; Governance is the main problem for many corporations, so we analyze the impact of corporate governance on financial efficiency 
of banking sector of Pakistan. This study examines the financial efficiency for the period of 2007-2012 includes 17 listed banks, Board size, Board meeting, non-Executive directors, bank size and Leverage take as an independent variables and used Return on equity (ROE) and return on asset (ROA) as a proxy variable for dependent variable Financial efficiency.

This study recommends that if we use accurate measures of corporate governance then we can improve the financial efficiency of banks. Corporate governance provides rules \& regulations to monitors and manages banks affairs, and it provides guidelines to the board of directors how to run the affairs and how to increase shareholder values and bank efficiency. Participation of Non-Executive directors in board increases board efficiency and protects the rights of shareholders. Adequate number of meetings in a year handles corporate affairs better and increases bank efficiency. The findings of this research show that corporate governance has significant impact on financial efficiency of banks.

\section{Limitations}

This study includes only 17 listed banks not all banks which are listed in Stock Exchange

This study covered the time period of 2007-2012

This study comprises few variables which are used in the past studies.

\section{References}

Andres, P., \& Vallelado, E. (2008). Corporate governance in banking: The role of the board of directors. Journal of banking \& finance, 32(12), 2570-2580. http://dx.doi.org/10.1016/j.jbankfin.2008.05.008

Andres, P., Azofra, V., \& Lopez, F. (2005). Corporate Boards in OECD Countries: Size, Composition, functioning and effectiveness corporate governance, 13(2), 197-210.

Bhagat, S., \& Bolton, B. (2008).Corporate governance and firm performance. Journal of Corporate Finance, 14(3), 257-273. http://dx.doi.org/10.1016/j.jcorpfin.2008.03.006

Caprio, G., Laeven, L., \& Levine, R. (2007). Governance and bank valuation. Journal of Financial Intermediation, 16(4), 584-617. http://dx.doi.org/10.1016/j.jfi.2006.10.003

Cheema, A. (2003). Corporate governance in Pakistan: issues and concerns. The Journal, 8(2), 7-19.

Cheema, A., Bari, F., et al. (2003). Corporate Governance in Pakistan: Ownership, Control and the Law. Lahore University of Management Sciences, Lahore.

Choe, H., \& Lee, B.S. (2003). Korean Bank Governance reform after the Asian Financial crises. Pacific- Basin Finance Journal, 11(4), 483-508. http://dx.doi.org/10.1016/S0927-538X(03)00051-9

Claessens, S., Djankov, S., et al. (2000). The separation of ownership and control in East Asian corporations. Journal of Financial Economics, 58(1), 81-112. http://dx.doi.org/10.1016/S0304-405X(00)00067-2 
Conger, J. A., Finegold, D., et al. (1998). Appraising boardroom performance. Harvard Business Review, 76, 136-164.

Connely, J. T., \& Limpaphayom, P. (2004). Corporate Governance in Thialand. Review of Corporate Governace in Aisa, 1-53.

Co-Operation, O. f. E., \& Development (2004). OECD Principles of Corporate Governance.

Eisenberg, T., Sundgren, S., et al. (1998). Larger board size and decreasing firm value in small firms. Journal of Financial Economics, 48(1), 35-54. http://dx.doi.org/10.1016/S0304-405X(98)00003-8

Fama, E. F., \& Jensen, M. C. (1983). Separation of ownership and control. JL \& Econ, 26, 301. http://dx.doi.org/10.1086/467037

Gillan, L. S., \& Starks, T. L. (1998). Corporate Governance propsals and shareholders activism: the role of institutional activism. Journal of Financial Economics, 275-305.

Haque, A., \& Tariq, A. (2012). Efficiency of Banks in Pakistan: A Non Parametric Approach. Business \& Economic Research (BER), 2(1). 1-12. http://dx.doi.org/10.5296/ber.v2i1.1711

Jackling, B., \& Johl, S. (2009). Board structure and firm performance: Evidence from India's top companies. Corporate Governance: An International Review, 17(4), 492-509. http://dx.doi.org/10.1111/j.1467-8683.2009.00760.x

Javid, A. Y., \& Iqbal, R. (2008). Ownership Concentration, Corporate Governance and Firm Performance: Evidence from Pakistan. The Pakistan Development Review, 47(4), 643-659.

Javid, A. Y., \& Iqbal, R. (2008).Does Corporate Governance Affect a Firm's Performance? A Case Study Pakistani Market. Journal of business and economics, 1(1), 11-23.

Klapper, L. F., \& Love, I. (2004). Corporate governance, investor protection, and performance in emerging markets. Journal of Corporate Finance, 10(5), 703-728. http://dx.doi.org/10.1016/S0929-1199(03)00046-4

Krivogorsky, V. (2006). Ownership, board structure, and performance in continental Europe. The International Journal of Accounting, 41(2), 176-197. http://dx.doi.org/10.1016/j.intacc.2006.04.002

Levine, R. (2005). Finance and growth: Theory and evidence. Handbook of economic growth, 1, 865-934. http://dx.doi.org/10.1016/S1574-0684(05)01012-9

Liang, N., \& Li, J. (1999). Board structure and firm performance: New evidence from China's private firms.

Lipton, M., \& Lorsch, J. W. (1992). Modest Proposal for Improved Corporate Governance, A.Bus. Law, 48, 59-77.

Mak, Y. T., \& Kusnadi, Y. (2004). Size really matters: Further evidence on the negative relationship between board size and firm value. Pacific-Basin Finance Journal, 12(1), 1-18. 


\section{Macrothink}

Business and Economic Research ISSN 2162-4860 2014, Vol. 4, No. 1

Moore, M. T. (2002). Corporate governance: An experienced model. Director's Monthly. 26(3), $1-9$.

Ong, C., \& Wan, D. (2008). Three conceptual models of board role performance. Corporate Governance, 8(3), 317-329. http://dx.doi.org/10.1108/14720700810879196

Prevost, A. K., Rao, \& R. P., et al. (2002). Determinants of board composition in New Zealand: a simultaneous equations approach. Journal of Empirical Finance, 9(4), 373-397. http://dx.doi.org/10.1016/S0927-5398(02)00002-6

Rebeiz, K. S., \& Salameh, Z. (2006). Relationship between governance structure and financial performance in construction. Journal of Management in Engineering, 22(1), 20-26. http://dx.doi.org/10.1061/(ASCE)0742-597X(2006)22:1(20)

Tricker, R. I. (1984). Corporate Governance: Practices, procedures and powers in British companies and their boards of directors, Gower.

Vafeas, N. (1999). Board meeting frequency and firm performance. Journal of Financial Economics, 53(1), 113-142. http://dx.doi.org/10.1016/S0304-405X(99)00018-5

Ward, J. L. (1991). Creating effective boards for private enterprises: Meeting the challenges of continuity and competition, Jossey-Bass.

Ward, J. L., \& Handy, J. L., (1988). A survey of board practices. Family Business Review, 1(3), 289-308. http://dx.doi.org/10.1111/j.1741-6248.1988.00289.x

Weir, C. (1997). Corporate Governance, performance and take-over: An empirical analysis of UK merger. Applied Economics, 29(11), 1465-1475. http://dx.doi.org/10.1080/000368497326291

Yasser, Q. R. (2011). Corporate governance and performance: An Analysis of Pakistani listed firms. Global Journal of Management and Business Research, 11(10).

Yasser, Q. R., \& Entebang,H., et al. (2011). Corporate governance and firm performance in Pakistan: The case of Karachi Stock Exchange (KSE)-30. Journal of Economics and International Finance, 3(8), 482-491.

Yermack, D. (1996). Higher market valuation of companies with a small board of directors.

\section{Appendix:}

Table 6

\begin{tabular}{|c|l|c|}
\hline \multicolumn{3}{|c|}{ List of Banks } \\
\hline \multirow{2}{*}{ Bank ID } & Name of Banks & Number of Observations \\
\hline 1 & Askari Bank & 6 \\
\hline 2 & Allied Bank & 6 \\
\hline 3 & Bank Al Habib & 6 \\
\hline
\end{tabular}




\begin{tabular}{|c|l|c|}
\hline 4 & Bank Alfalah Limited & 6 \\
\hline 5 & Bank of Punjab & 6 \\
\hline 6 & Faysal Bank & 6 \\
\hline 7 & Habib Bank Limited & 6 \\
\hline 8 & Habib Metro Bank & 6 \\
\hline 9 & JS Bank & 6 \\
\hline 10 & KASB Bank & 6 \\
\hline 11 & MCB & 6 \\
\hline 12 & Meezan Bank & 6 \\
\hline 13 & National Bank of Pakistan & 6 \\
\hline 14 & NIB Bank & 6 \\
\hline 15 & Samba Bank Limited & 6 \\
\hline 16 & Soneri Bank Limited & 6 \\
\hline 17 & United Bank Limited & 6 \\
\hline
\end{tabular}

\section{Copyright Disclaimer}

Copyright reserved by the author(s).

This article is an open-access article distributed under the terms and conditions of the Creative Commons Attribution license (http://creativecommons.org/licenses/by/3.0/). 